\title{
Networks and Territorialities:
}

an ethnographic approach to the so-called cracolândia ["crackland"] in São Paulo

Heitor Frúgoli Jr.

Professor in the Department of Anthropology of the Faculty of Philosophy, Literature and Languages, and Human Sciences at the University of São Paulo - FFLCH-USP

Enrico Spaggiari

PhD degree student, Social Anthropology - USP

\section{Resumo}

Esse artigo tem como objetivo apresentar uma investigação mais sistemática do que se convencionou chamar de cracolândia, para além de uma série de representações estigmatizantes atreladas ao bairro da Luz e ao centro de São Paulo, principalmente pela mídia impressa e televisiva. O uso do crack está se tornando um tema de crescente preocupação no Brasil, com notícias recorrentes sobre a "proliferação de cracolândias" em várias cidades, $\mathrm{e}$ devemos compreender o que está em jogo em cada uma dessas configurações. A partir da observação etnográfica das redes de relações e conexões, procuraremos trabalhar a ideia da cracolândia como uma modalidade de territorialidade itinerante dentro de um contexto multifacetado e marcado por inúmeras variações situacionais. Essa reconstituição etnográfica é baseada principalmente em nossas interações com o Centro de Convivência É de Lei, uma ONG que trabalha com ações voltadas à redução de danos junto aos usuários de crack na região em questão. Nesse contexto, as ações do É de Lei ocorrem dentro de um campo de mediação assinalado também pelas ações de agentes ligados a entidades públicas, de outras ONGs e igrejas, bem como policiais, seguranças particulares, lojistas, moradores e transeuntes. Um dos desafios consiste em compreender e explicar tal territorialidade frente às recentes dinâmicas políticas que reconfiguram o contexto pesquisado, marcado pela presença dos nóias, categoria relacional acionada de forma múltipla e recorrente para se referir aos usuários de crack.

Palavras-chave: bairro da Luz, territorialidade, crack 


\section{Abstract}

The aim of this paper is to present a more systematic investigation of what is commonly called crackland (cracolândia), going beyond the stigmatized representations of the Luz neighborhood and the center of São Paulo shown especially by the press and television. The use of crack cocaine is currently becoming a theme of increasing concern in Brazil, with repeated news about the "proliferation of cracklands" in various cities, and what each of these means must be understood. Exploring networks of relationships and connections from an ethnographic perspective, we will work with the idea of crackland as a type of itinerant territoriality within a multifaceted context, and marked by multiple situational variations. This ethnographic reconstitution is mainly based on our interactions with "É de Lei", an NGO that works with harm reduction for users of crack cocaine in the region in question. The actions of É de Lei take place within a field of mediation which also involves actions of agents linked to public authorities, to other NGOs and to churches, as well as policemen, private security guards, shopkeepers, residents and passers-by. One of the challenges consists of understanding and explaining this territoriality in view of the recent political changes in the context researched, characterized by the presence of "noias" (a word derived from the term paranoia), a relational category used to refer to crack cocaine users.

Keywords: the Luz district; territoriality; crack 


\title{
Networks and Territorialities:
}

\author{
an ethnographic approach to the so-called cracolândia \\ [“crackland"] in São Paulo'
}

\author{
Heitor Frúgoli Jr. \\ Professor in the Department of Anthropology of the Faculty of \\ Philosophy, Literature and Languages, and Human Sciences at the \\ University of São Paulo - FFLCH-USP
}

\author{
Enrico Spaggiari \\ PhD degree student, Social Anthropology - USP2
}

\section{Introduction}

We must very briefly return to the route covered up to now by the research project presented here, to explain the aims of this paper. Our ethnographic

1 Paper presented by Heitor Frúgoli Jr. in the panel "Uneasy Places: shifting research boundaries and displacing selves" at SIEF 2011, the tenth international congress of the International Society for Ethnology and Folklore, held at the Faculty of Social Sciences and Humanities of the New University of Lisbon, Lisbon, April 17-21l, 2011; a French version was presented at the Journées d'Études "Frontières et mouvements de la ville: comparaisons internationales en anthropologie urbaine" of the Centre d'Études Africaines, Laboratoire Architecture et Anthropologie and Laboratoire d'Anthropologie Urbaine of École des Hautes Études en Sciences Sociales (EHESS), Paris, May 3-4, 2011; a Portuguese version was presented at the PhD in Sociology Program Conferences of the University of Porto, Porto, May 13, 2011. Our special thanks to Michel Agier for the translation of our paper into French, for the comments of Stéphane Dufoix (at the Journées d'Etudes above mentioned) and also to Frédéric Vidal, Isabel Rodrigues and João Teixeira Lopes. The participation of Heitor Frúgoli Jr. was made possible by FAPESP - São Paulo Research Foundation, EHESS and University of Porto. The study has been conducted since 2007 by the Anthropology of the City Study Group (Grupo de Estudos de Antropologia da Cidade (GEAC-USP), later with the support of CNPq (National Council for Scientific and Technological Development) (Frúgoli Jr., 2008-2010). Paper translated by Alison Jane Reilly Francis.

2 This article is based on field research conducted by Heitor Frúgoli Jr. and Enrico Spaggiari (Paula de S. D. Faria took part on one occasion). It also benefited from the collaboration of participants in the broader research: post-graduate students Guilhermo A. Aderaldo, Giancarlo M. C. Machado e Natália H. Fazzioni, graduates Isadora Z. Da Fonseca and Bruno Puccinelli, and undergraduates Weslei E. Rodrigues, Karina Fasson and Julio C. Talhari: Jessica Sklair, Carlos F. de Aquino, Daniel de Lucca R. Costa, Inácio C. D. de Andrade, Fabio C. Julião, Marina A. Capusso, Paula S. D. Faria , Laís Silveira and Bianca B. Chizzolini also took part (all are or were part of the GEAC). For an idea of the first stages of this investigation, see Frúgoli Jr. and Sklair (March 2008 and Dec. 2009). We should also like to express our gratitude to all those we came into contact with and interviewed throughout this research, especially the members of the "Centro de Convivência É de Lei” (an NGO meaning literally “It's (from) the Law”), the main interlocutors in this text. 
investigations $s^{3}$ have basically sought to reconstitute several networks of relations and connections between two relatively common ways in which the Luz region in downtown São Paulo is represented: as a cultural neighborhood (made possible by the creation and strengthening of various cultural institutions by the state since the mid -1980s) ${ }^{4}$ and as cracolândia [crackland], a stigma of degradation and crime resulting from the presence of many crack cocaine users in the neighborhood's streets, including homeless men, women and children, sex professionals etc.

The Luz neighborhood is marked by high urban and social density, and includes several buildings and cultural institutions registered as heritage sites. The first of these to be recognized for its historical importance was the Luz train station (Estação da Luz), whose current building was inaugurated in 1901, and whose recent renovation included the installation of the Portuguese Language Museum (Museu da Lingua Portuguesa) at the station site. In the area surrounding the station, a significant collection of cultural institutions have recently been renovated - such as the Pinacoteca do Estado or partially adapted for new uses, as in the case of the Sala São Paulo concert hall, which was constructed inside the old Júlio Prestes train station and is today home to the State Symphony Orchestra. These institutions have drawn a new influx of middle and upper class people to the old city center for the purpose of cultural consumption (Bourdieu, 2007 [1979]). A predominantly working class population, however, has occupied the residences, streets and city squares of the region for many decades. Luz is host to a significant number of cortiços, ${ }^{5}$

3 For a synthetic approach to the importance of ethnographic practice in the study of the city, and to the potential of urban ethnography, see Durham (2004 [1986]), Agier (1999), Magnani (2005 [2002]), Cordeiro (2003), Peirano (2005), Frúgoli Jr. (2007), Eckert (2010).

4 This was first seen in the project Luz Cultural (in the administration of the PMDB party, 1983-1986), and continued in the following decades by means of the Monumenta-Luz and more recently the Nova Luz (see Frúgoli Jr., 2000, 72-73 and 103-109; Kara-Jose, 2007). This role has been played by different government spheres, especially state government and more recently by the municipal administration, with a certain continuity between the administrations, and co-ordination between different government plans defined by policies connected mainly to the PSDB party. The sphere of cultural institutions and historical heritage has been emphasized in this route, although it is increasingly related to strong real-estate interests.

5 A cortiço is a type of illegally rented accommodation occupied by low income families found in Brazilian cities for many decades. Cortiços are typically large, dilapidated and over-crowded houses, inhabited by multiple families who share bathrooms and cooking facilities. Living conditions in these houses are generally very unhealthy and unsafe, and residents are at great risk from fire. The main advantage of cortiços is their central localization, as they are usually found close to opportunities for work and urban services and utilities. 
and informal commerce, prostitution and the trafficking and consumption of crack cocaine are common in many of the region's public spaces. This stigmatization dates back a long time and is also related to previous symbols like that of a type of "red light district" known as the "Boca do Lixo," which operated there. Some of those interviewed refer to the use of crack cocaine in the streets of Luz and the vicinity as early as the 1990 o. $^{6}$

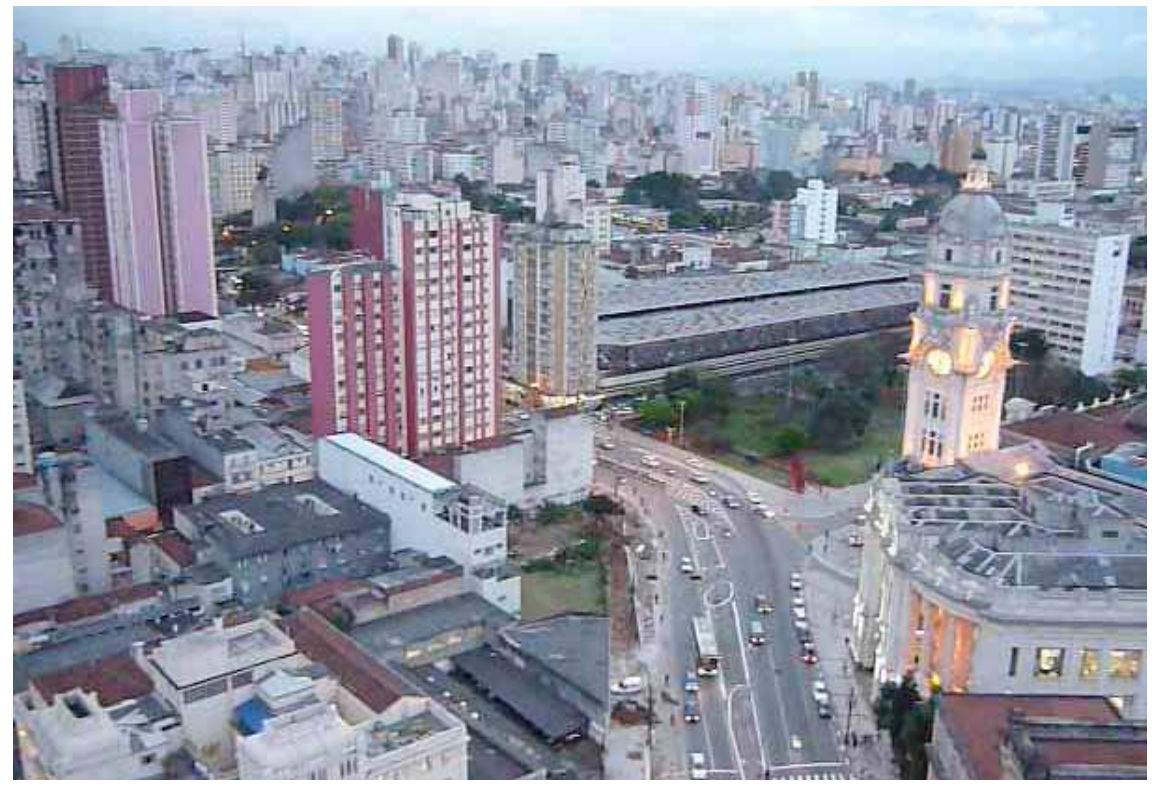

View of the Luz region from the top of the Santa Josefa building: in the center, Mauá Street; at the rear, Júlio Prestes Square and the old bus station; to the right, Júlio Prestes Station (photo: Heitor Frúgoli Jr.).

The polarity between cultural neighborhood and cracolândia can also be related to the opposition between the "requalification" (renovation) and deterioration that have been going on since the early 199os in downtown São Paulo, although these processes can be considered the results of other previous oppositions.7

These polarities are obviously not restricted to the rhetorical field. During certain urban interventions - in which several social and cultural conflicts erupted and intensified - they have displayed different and opposing worlds.

6 According to Uchôa (1996 apud Silva, 200o, 19), the more intensive use of crack cocaine in the streets of Luz began in 1991.

7 For a systematic analysis of requalification and a related lexis see Frúgoli Jr. (2000; 2006) and Peixoto (2009). 
Our ethnographic practices have concentrated on parts of the local population of Luz - especially shopkeepers and residents -, on people who commonly use the streets and on some urban services. We also focus on social actors who are related (often as mediators) more closely to the so-called cracolândia - which is seen as a kind of itinerant territoriality, as we shall see in the following pages. This article focuses precisely on this aspect. ${ }^{8}$

From an analytical perspective, given the social, cultural and urban characteristics of the neighborhood in question, we work with the hypothesis that widespread networks of sociability exist in the region. The ethnographic starting point of these is in urban areas characterized by precarious urban conditions (Agier, 1999, 110-197). At the same time, we have tried to understand the type of public space that results from specific interactions (Joseph, 2005 [1998]) that are stimulated in part by the fact that this is a busy downtown neighborhood with many passers-by. Within the ethnographic focuses, special attention has been given to the spatial practices of appropriation and production of a neighborhood (Certeau, 1994 [1980], 199-215).

By studying this neighborhood, we inevitably developed a more systematic view of what is customarily called cracolândia. It is much more than a series of highly stigmatized representations given by the media, which in a certain way, are a current form of criminalizing poverty. The media gives the impression that crack use and poverty is found throughout the neighborhood and the vicinity, and not just a part of it (as expressed in hundreds of news articles studied). ${ }^{9}$

When we asked the local population, tradesmen and people who use the streets in the Luz district, what they thought of the neighborhood, they often

8 In other words, this text, dealing mainly with social actors more directly related to so-called cracolândia, does not exhaust our ethnographic approaches to Luz which, are connected to various dimensions represented here to different extents. Among the other areas - all with emphasis on ethnographic observation and not only interviews - we can point out contacts with people who live there (in different types of buildings and residences), those with commercial establishments (especially those affected by the recent urban interventions), shop assistants, pedestrians, private guards, sex professionals and those who use the streets and services of the neighborhood. We also observed people who use the three cultural institutions (Pinacoteca, Sala São Paulo and the Museum of the Portuguese Language) as well as Parque da Luz, and other areas for entertainment (samba halls, "chorinho" (a type of Brazilian music) and soccer games) organized by musical groups and commercial establishments (Frúgoli Jr. and Aderaldo, ago./2010).

9 This is clearly visible in the huge amount of material in the Brazilian press that we have collected since 2005. 
mentioned the presence of the noia(s), ${ }^{10}$ a native term often used to describe the crack cocaine users, and which was used much more frequently than the term "cracolândia" (which is prevalent in the press and on television). A typical response was, in short, the following: "apart from the noia(s), the district is good." Although Luz and Centro are part of the same spatial area, ${ }^{11}$ the term Luz is clearly linked to the noias - marked by their physical presence in the streets and symbolically associated with a series of stigmas, such as grime, danger, threats to safety (mainly at night), drugs, trouble, shame etc. (Frúgoli Jr. and Sklair, Mar.2008, 5-6 and Dec.2009, 124-125). ${ }^{12}$

Our hypothesis is that cracolândia is a kind of itinerant territoriality (Perlongher, 1987 and 2005 [1988]), characterized by many kinds of conflicts (Arantes, 1996), which located it in a certain urban area. However it may move further depending on the type of repression or intervention practiced, and the dynamics of its own internal relations. In this sense, this study is similar to, but also different from that carried out by Bourgois (2003; 1997 [1989]), which basically focused on agents connected mainly to the sale of crack (crack dealers) at certain points of El Barrio (Hispanic Harlem, New York). ${ }^{13}$ Although our work also deals with people who are often identified

10 The term noia may be defined, only in introductory terms and without going into the relational meanings connected to the term "as what crack addicts call the anguish and feeling of persecution that accompanies the state of euphoria generated by the drug. Its origins lie in the word paranoia" (Monteiro, 3/9/200o, our translation). According to participants of É de Lei "to be in the noia" may also refer to a state in which the user is when he is "desperately" ("vidrado") looking for crack.

11 In this case, the qualities mentioned slip easily from those in the neighbourhood to those found in the inner city: a train station, buses, the metro, bakeries, supermarkets, medical centres and the Santa Casa hospital. People also mentioned the many work opportunities (even if it is unsafe and unstable work) in the central region such as that in the informal trade, in various types of services, the collection of recyclable material etc.

12 In many accounts, the people interviewed referred to them as a chronic, long-standing problem, which has affected the neighbourhood for many years.

13 Philippe Bourgois was in São Paulo in December last year and his impressions of crackland (based on a single visit to the corner of Cleveland with Helvétia Streets) were the following: "It is certainly the friendliest and most sociable scene of crack that I have seen. I have never seen anything before like what there is here. In other places you don't see this level of relaxation and sociability, with people making music happily and cheerfully while they smoke crack. Very impressive. In Amsterdam there is something similar in a space especially designed for socialization, but it is a place with nurses and assistance. Here it is spontaneous [...] Usually smoking crack is totally destructive. Here, among 70 people, most of them were still able to smile and talk. That brings some hope that Brazil might find some ways of dealing with the problem [...] I believe in harm reduction policies, which create links with the reality outside crack [...] I'm in favor of programs that include work, music and religion. This reduces the need for so many police patrols and doesn't overload the health system [...] In the United States there are fewer users in the groups 
as homeless, our focus is basically on crack users, due to their widespread presence in the streets of the Luz neighborhood and their occupation of other public spaces, as well as their more visible relations with other social actors in the streets.

Our approach perhaps comes relatively closer to the concept of a psychotropic territory (Fernandes, 1995), whose "main communicational feature is minimal interaction and which is structured as an interstice of space and time" (Fernandes, 2000, 146). According to this author, when repression of drug trafficking is increased in a certain territory, ${ }^{14}$ there is generally a move to the surroundings or to neighboring districts, in which the actors involved with drugs are diluted by adjoining zones and change their interactive strategies, through the exploitation of other urban interstices (1995, 27-28).

Before our first field trips, the specific perimeter of so-called cracolândia (as defined by the municipal government and widely covered in the press) was precisely the "pentagon" where the municipal project "Nova Luz" (New Luz) was to be installed (São Paulo City Hall, Dec.2005). These rigid perimeters revealed strategies of urban intervention designed to raise property values.

In our initial observations in October 2007, when the first demolitions in this "pentagon" had already taken place, the main concentration of crack users had already moved a few blocks away, outside these perimeters.

There are also times when other public spaces downtown are visibly occupied by crack cocaine users. This is partly because many of them move to another place, especially when more comprehensive and integrated operations by local government take place in Luz, as we will see further on.

Thus, as we have already said, the interventions result in an increase in certain polarities due to a number of factors. We began to work ethnographically in the so-called cracolândia with the hypothesis that the territory was undergoing a process of dispersion and movement to a variety of more restricted strategic points and thus spreading out from the Luz region.

of dependents, but they are much more violent. There isn't this level of sociability in Canada, either. This hasn't been seen before in my studies and has to be studied and used to seek solutions to the problem. In Colombia, they are repressed more and they become more violent and out of control. In Três Esquinas in Bogotá, the police only go in if they are making a raid (Brandalise, 10/12/2010, our translation).

14 Based on the analysis of the districts of Casal Ventoso (Lisbon) and Sé (Porto). Other territories were included later, like the Bairro São João de Deus (Porto) (Fernandes e Ramos, 2010). 


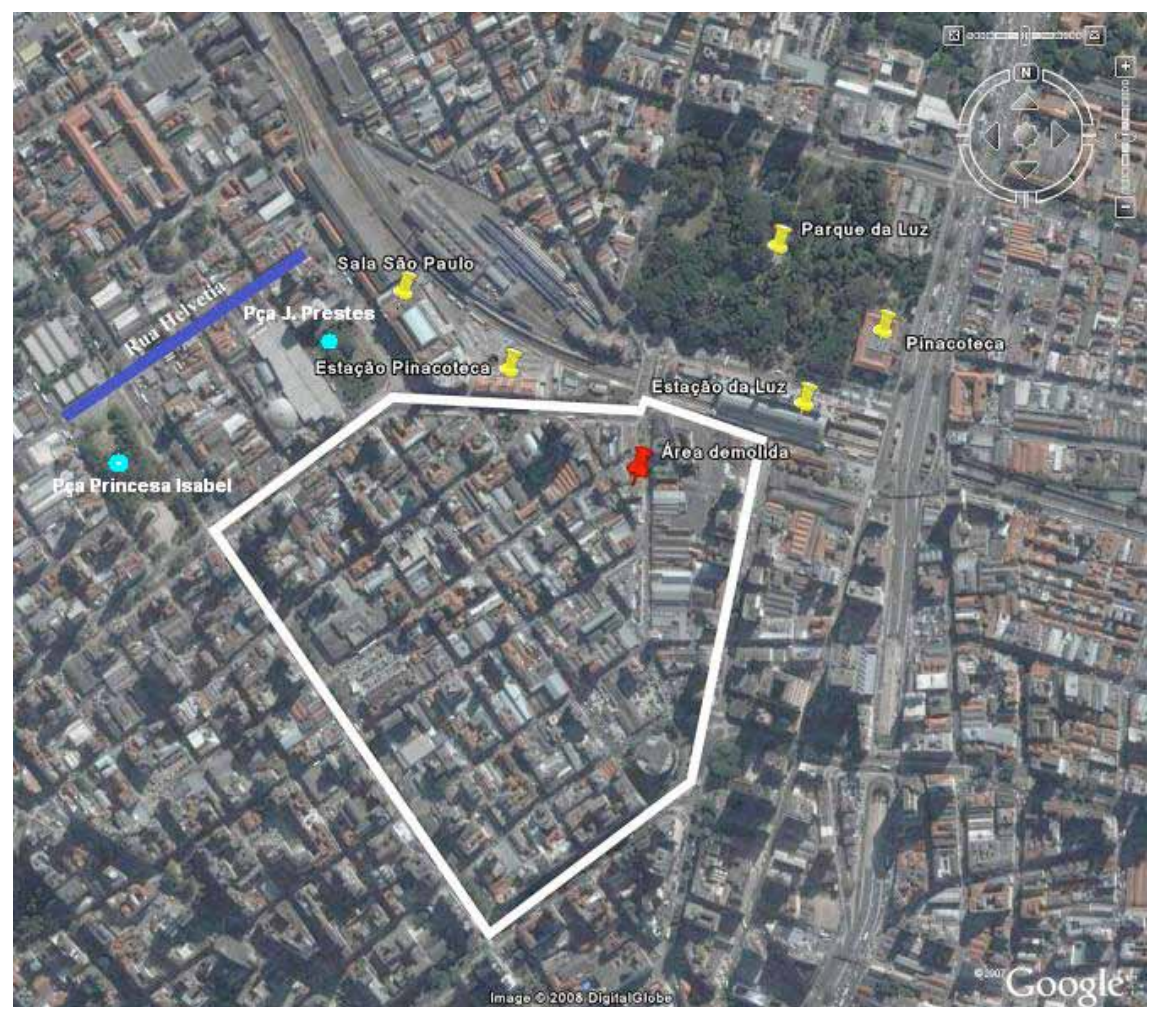

Aerial photo of the Luz neighborhood (and surroundings). In white, the perimeter of the New Luz project (the former area of cracolândia, according to the municipal government). In red, the blocks of the first demolitions. In yellow, some well-known sites in the region (cultural institutions, train and subway station, park). In blue, a street frequently used by crack users during our fieldwork; in light blue, two squares where they can also be found.

Thus, considering cracolândia as a type of itinerant territoriality and a field of relations, we have sought to establish ethnographic contact with this multifaceted contextmarked by countless situational variations. We have contacted a series of organizations, NGOs and various institutions that are characterized by different types of relations with certain local social actors. The relation established by each one of these institutions with this context reveals different facets of the region. There are entities that focus on aid to homeless children in the region, or to prostitutes, and those which establish relationships with various actors, in an attempt at harm reduction, not to mention others that seek to offer a religious message and help to different groups.

Each one of these groups describes or identifies these actors differently, even though they may sometimes converge on the use of crack. In this article we will describe our interactions with the organization "É de Lei" in its relations with the context in question. These relations take place through actions aimed 
at harm reduction, especially for crack cocaine users, by means of direct contact in the streets in the Luz neighborhood and at a reception center. The emphasis will be on our description of this particular type of action, which also serves to help construct a kind of identity for those attended.

Through regular contact with this organization we were able to come closer, from an ethnographic point of view, to crack cocaine users in the streets of Luz and the neighboring regions. Our focus is predominantly on the relations established by this organization with the crack users. In other words, we are interested in understanding certain types of mediation established with so-called cracolândia, through which we intend to arrive at other types of mediating agents involved in this field.

It should also be emphasized that we took an ethnographic approach that does not seek to (nor could it) substitute the numerous and increasing interpretations of the theme (especially in the press and on television), but to analyze it from the point of view of our research experience. ${ }^{15}$

\section{The "É de Lei" organization and the practice of harm reduction: access to crack cocaine users}

The reception center of É de Lei, an organization that works to reduce risk among crack cocaine users, was established in 1998 and the entity became an NGO in 2001. It first focused on users of intravenous drugs, and conducted "fieldwork"16 in nightclubs and bars. Little by little, they eventually opened a reception center where drug users could spend time together off the streets.

According to Marina dos Passos Sant'Anna - the president and coordinator of the organization in $2007^{17}$-, the focus of attention started to shift to attending crack cocaine users in 2002, after the presentation of a pilot plan to

15 Curiously enough, two researchers (a Romanian and a Frenchman) asked informally (at the meeting of SIEF which we have already mentioned) if we had tried crack during the research. It must be recognized that in some fields of investigation, such as studies on Santo Daime communities (Labate et al, 2008), there are anthropologists who try ayahuascha tea (sometimes to take part in the religious rites), perhaps, because as one colleague once jokingly commented: “It's better to be deep inside than far outside..." Nevertheless this never occurred to us as a relevant issue, especially considering that good ethnography never consists of trying "to get into the skin" of the natives (Geertz, 1997 [1983], 19 and 85-107). Not to mention that the vulnerability that most of the people there experience is impossible to experiment "rapidly," even if journalists sometimes try to do so ("homeless for a day," "collector of recyclable material for a day" etc.).

16 As the agents of the organisation themselves call this activity.

17 The year of our initial observations and interview with her (May 10,2007). 
the Brazilian Ministry of Health. The organization was then chosen to work with four others from different federal units.

According to Ms. Sant'Anna, who joined É de Lei in 2003 - when the group was already working in cracolândia - various reasons led to the gradual change of the target public, such as the decrease in the number of drug addicts using intravenous drugs, the death of users, and their switch to other types of drugs. She also pointed out a more public nature in the use of this drug: "it was much more explicit, done in the street itself." This change also stimulated É de Lei to adapt new work methods.

Although the organization received little funding at the beginning for its work to distribute materials and lip balms to the crack cocaine users, because "for the authorities, there is no profit in harm reduction," it succeeded in setting up a mobile unit in 2004, to have access to users in the streets downtown. According to Sant'Anna, the aim was to "take the headquarters into the field" and convince the users to visit É de Lei's reception center. ${ }^{18}$

For one week (Dez.2007), ${ }^{19}$ we observed the activities and services they conducted at the reception center, a space for interaction for drug users, where the use of drugs is obviously forbidden, and where discussions are held and reflection encouraged about preventive sexual practices and the abusive nature of drugs. However, our emphasis was on the action of É de Lei in the streets in the Luz district and region.

É de Lei's field work has been carried out in the downtown area, more precisely in the area called Luz..$^{20}$ The first efforts were difficult, both in terms of relationships with the police and with the users themselves, many of whom distrusted the members of the organization. The distribution of materials, for example, passed through various stages. They first tested distribution of wooden pipes, but these were not widely accepted by the users, who preferred metal ones, usually adapted from car antennas. The entity now distributes silicone cigarette holders, cocoa butter lip salves and condoms,

18 It is not easy for some users to access the reception centre because many addicts were barred by the private security guards of the commercial gallery where the organisation has two rooms on the top floor.

19 Afterwards other (shorter) visits were made.

20 On various occasions the agents of the É de Lei used the term "Luz" to refer to the region where they distribute the material. In a certain way there was a reduction of the Luz neighbourhood when they spoke, to the perimeter of cracolândia. In contrast, "Centro" was a term with a wider scope since, as one of the agents said, "there are regions here in the centre where there are no users, but these are closer to Consolação and República.” 
in addition to informational leaflets about the reception center and disease prevention. The relationship with the police also made the first few months of work in the Luz region difficult. According to Marina, the police "usually would approach the team, to inspect us."

For this and other reasons, according to Santa'Anna, it took some time for É de Lei to be accepted in the region, although we have observed the friendly and receptive way in which the organization's agents are almost always received by the crack cocaine users, which is probably the result of trust constructed over time. Neverthelss, at times their actions were questioned by the users. During one of our trips with É de Lei, ${ }^{21}$ on Oct. 16, 2008, a boy who said he used crack commented (to the agents of É de Lei and to us) that the work of harm reduction or prevention would not help "to solve the problem." A possible solution would be to bring "a damaged human organ in a glass jar with formalin to show us." "You have to shock us," he said. On the same day another user (who appeared to be older than $40{ }^{22}$ commented: "It's utopia to get this cigarette holder (distributed by the agents). It makes us feel as if it's 'legalized'." ${ }^{23}$ We were told that one day a user accepted the silicone cigarette holder, although he said he intended to share it with other people (in other words, violating the proposal that they be used individually by the agents to reduce harm).

The team conducted field work once a week, always in the afternoon between $3 \mathrm{pm}$ and $6 \mathrm{pm}$, with two or three members. ${ }^{24}$ Leaving the organization's headquarters located in a gallery on Av. 24 de Maio, the team walked through the streets and avenues downtown to reach the Luz neighborhood.

The team expressed visible concern about the health of the users during these trips, and attempted to provide what medical help was possible under the circumstances. Once (in Dec. 2007), in the Praça Júlio Prestes (Júlio

21 Whenever we went, we wore T-shirts identical to those worn by the agents (they were red, orange or yellow with the name of the organization written on them), and we sought above all to observe their actions, although we sometimes helped in the distribution of material. Our interactions with the users were mainly in triangulation with the agents.

22 We were told very rapidly (since it is very difficult to establish more lasting contact in the streets due to the itinerant character of the field of É de Lei and also because of the ways in which the space is used by the crack users) that he had been arrested for using marijuana.

23 "Legalize it" is the title of a reggae song by Peter Tosh about the need to legalize the use of marijuana.

24 It is usually necessary to have three people in the field and a member of staff on duty in the reception centre. Due to the limited number of staff and voluntary workers, the weekly field trip was at times cancelled. One of the agents confirmed that until 2006, the team had made 3 field trips per week, two of which were for direct intervention with the users and one to accompany users to be attended at public health services. 
Prestes Square), one of the agents helped a black boy put disinfectant on an injured heel. On other occasions we observed initiatives of É de Lei to create partnerships with health organizations that work in the region.

Despite the difficulties, one of the agents pointed out that the constant presence in the field helped to create ties with the users that were a little more significant, and also increase relations with other actors - shopkeepers, residents, prostitutes and transvestites - who act in the so-called cracolândia.

\section{New arrangements in the uses of the space: "today there is a march of 'noias!"' 25}

Notified beforehand by the Ministry of Health about "Operação Limpa" ("Operation Clean Up"), which was to take place in March 2005, ${ }^{26}$ the agents of É de Lei did not accept the invitation to take part, since they did not agree with the proposal. Bruno Ramos Gomes, an agent of É de Lei, pointed out that the years after "Operação Limpa" were difficult, since the municipal government did not want to cooperate with their field actions because the aim of the operation was to "clean up" the area known as cracolândia. That is, they wanted to remove the crack users from that region through a combination of actions - with emphasis on police intervention.

According to Marina, after Operation Clean-Up in the "pentagon" identified as cracolândia, when many hotels were closed, the crack cocaine users migrated to the region near the former central bus station, opposite the Júlio Prestes train station and near Luz Park and Praça Princesa Isabel (Princesa Isabel Square). However, she observed that "the users disappeared with Operation Clean-Up, but many of them are coming back."

Consequently, the perimeter of the Nova Luz project (the prime target of Operation Clean Up) continued to be attended by É de Lei. However, their work was extended to the new places where users gathered as we saw on several occasions.

25 This was said by a crack user on Sept. 8, 2008.

26 Performed by the local authorities including the police, health inspectors and sectors connected to assistance, health, and public cleaning and which resulted in "2,216 people stopped and searched, 426 paper wrappers containing crack cocaine confiscated, 12 people caught dealing or carrying drugs, 3 hotels closed and their entrances sealed with concrete, 3 guns and 50 cell phones confiscated, 369 adults and children taken to homeless shelters, 2 wanted men arrested and 5,200 pirated CDs confiscated" (Folha de São Paulo, Oct. 3, 2005, our translation). 
On most of the field trips, the preferred destination was Rua Helvétia (Helvétia Street), where there was the largest number of users. This represented a slight change in territorial focus in relation to former routes, when the main site of the group's field work was Princesa Isabel. Bruno explained that they decided to work there because of the large numbers of users on Helvétia Street in the previous few months.

Oct. 9,2007 - We left the reception center about 4 p.m. As we realized throughout the field trip, it was an atypical day, since the night before there had been a police chase and exchange of gunshots in various places in downtown São Paulo. So on that Tuesday, there was a strong presence of military police in the region. The first point of concentration encountered was Princesa Isabel Square, where there were about 40 users, mostly men, many under trees on blankets, mattresses, newspapers and in tents. We helped with the distribution of cigarette holders and cocoa butter lip salves, and we spoke to a pregnant woman, who refused condoms, stating that she only had sexual relations with her husband. The distribution of condoms was not restricted to crack users. A man known as "Aranha" ("Spider") showed up, who said he lived in the streets and sometimes smoked crack. He was easily recognizable because his face, was tattooed with spider webs. He was angry, and complained that nobody had turned up the night before to defend them, when the municipal cleaning crew, supported by a police car, "cleaned up" the square by removing their belongings (mattresses, blankets etc.). He gradually calmed down, especially after interacting with an agent of $E$ de Lei, who demonstrated that he had a great deal of experience. Before moving on, we talked to two boys who said they no longer used crack and that they had come to get condoms. The second point we intended to visit, almost could not be attended that afternoon; Helvétia Street was empty. The team was at first concerned by soon discovered why, when we saw two police cars (on the corners of this street with Ana Cintra and Dino Bueno Streets). The team stopped to talk to the police and asked about the reason for the action. It is interesting to note that some users were seen both at Helvétia and in Princesa Isabel, which possibly suggests continuous circulation in that region (which a policeman at Ana Cintra that day called the "new cracolândia"). After distributing a few supplies in Helvétia and nearby, we went on to Júlio Prestes. There we found the largest concentration of users of that day, around seventy people. Most of them were men, and many were black or mulatto boys. Some of them had wounds on their arms and legs and dirt all over their bodies. The conditions of these young men were the most shocking conditions we 
found that day. The agents of É de Lei did not approach the users - since there were too many people to do so calmly and efficiently - and preferred to observe from a nearby spot and wait for them to come closer (various people were smoking crack at that moment). Some boys came over quickly to get the supplies. One of the agents made a point of greeting the boys, who were visibly under the effect of the drug. They gradually came increasingly closer, when after 5 minutes of distribution, a police car approached. The siren, which could be heard from afar, caused the users to disperse rapidly. The few that had remained, moved away after a policeman got out with his baton in his hand. We stayed a few more minutes in the square. One of the agents of $E$ de Lei showed us some hotels and cortiços nearby and confirmed that they had even conducted field trips in boarding houses and cortiços. The field trip was supposed to end at Júlio Prestes, but we asked the agents about the concentration of users in the area still called cracolândia. Although they said that there had been a decrease in the number of users there, they decided to make their way back through the "old cracolândia" (the territorial borders of the "New Luz" project). There we found some users; the largest group, about ten young people (men and women) were sitting on Protestantes Street and smoking crack. There were some shops and hotels - many of which were closed with brick barriers. An É de Lei agent said that some of these places are still used for consumption (and certain hotels include the drugs in "the package" and final price of the room).

Given its new arrangement of work in Luz, É de Lei underwent a period of reorganization in 2007 in an attempt to strengthen its ties with other groups and organizations such as Casa Taiguara (a shelter for street children and adolescents), the Forum Centro Vivo (The Alive Inner City Forum) and evangelical groups that work in the region, which would prove to be fundamental for its work to continue. Under the new situation, the organization stopped mediating contacts between users and the homeless with the network of shelters in the region to obtain vacancies.

Other changes in the region (among certain permanent aspects) were noticed during the fieldwork in 2008, as reported below:

Sept. 8,2008 - When we approached the first significant concentration (on Barão de Piracicaba Street as it approaches Helvétia) we saw that there were many more users than in the previous year and due to police repression, they moved around the streets much more. The interactions of É de Lei, as did our own, had to adapt to this in some 
way. Initially we interacted with a relatively numerous group, and while we were talking to a man aged 28 who had been "in this" for 5 years (he had a two-year-old daughter), two policemen arrived on motorcycles and the users dispersed, with the exception of three or four who were sleeping, or strongly affected by drugs, as well as a man in a wheelchair and a black woman (who complained of conjunctivitis) and a young pregnant girl (the police only took some notes). We went on to Helvétia, where a collector of recyclable material who had been in jail was attended. He had recently recovered from a boil and his feet were still very swollen. A prostitute who wore a wig (who was known to the agents, and who told us she had been in the region for 18 years) asked for "lots of condoms," since "the boss had become infected by AIDS and now everyone had to take precautions." At this moment the police arrived by car, dispersing those who were on the streets. A group of users passed us by and one said: "today there's a march of 'noias!" On Dino Bueno Street, the police were searching a small number of users sitting on the ground, while a little further on a security guard was forcing users to move away from the front of a shop. When we reached Princesa Isabel Square, a teenager (who was asking drivers for money at a traffic light) ran up to us and hugged the agents of É de Lei (and us as well). The police were also speaking to some people who were lying down in the square and while we were returning to the reception center by Guaianazes Street, we saw about ten boys and girls smoking crack and listening to the conversation between the agents and a young man who had been in jail for 12 years. We heard another comment that "after getting an anesthetic in the head, it's fine!"

Sept. 15,2008 - We started the work in Princesa Isabel Square (where there were about twenty users), and the second point was Helvétia Street. There were more than two hundred users along the street that afternoon. Since attending such a large number of users simultaneously is difficult, the team preferred to concentrate on smaller groups that preferably were not using drugs at the time. When we were approaching one of these groups, of 10 users, leaning against the wall of a house, we thought it had begun to rain. But we soon noticed that there was a water hose on the side of the house, full of holes from which the water was dripping. We discovered that these hoses were used in other houses on the same street to make the users on the sidewalks go away.

Oct. 16,2008 - The work was conducted under light, intermittent rain. On Barão de Piracicaba Street, where there was a lot of garbage on the sidewalks, a boy who 
was smoking crack with three others apologized (good humoredly) when he saw us: "Sorry about the auê! [mess]" 27 (he said that he already knew the É de Lei). In Helvétia there were about 8o people, many of them sitting on the sidewalk smoking crack. One boy, who stood out from the others since he was better dressed and well built, approached and also sat down on the ground to smoke crack. A woman (who had almost no teeth) commented to us that she doesn't like crack and only smokes marijuana (as well as two packs of cigarettes a day) and that she had been in prison for two years. A pretty, very thin girl passed by and later we saw her in other places we went. A boy was looking at us rather suspiciously, but everyone around us interacted in a friendly way with the agents of É de Lei. The arrival of police cars made some people get up, but someone said "relax, they aren't after us today, today is operation hotel," and in fact about six or seven armed police entered a hotel on the street. One boy caught our attention when he said "I know how to use drugs and I know how to look after myself." Acting as if he were different from the others, he also said "I have somewhere to sleep and food to eat." The same day, another boy who looked about eighteen, refused to be called a noia: "The noias are those who are lying around over there. I take drugs, but not all the time."

Between 2007 and 2008 there was a considerable increase in the number of users, especially in the region of Helvétia, as the members of É de Lei had foreseen. In our observations between September and October of 2008, there were occasions when we counted as many as 200 users along this street. At the same time, there were fewer users on Princesa Isabel than in the previous year. ${ }^{28}$

Certain changes in the dynamics of the occupation of the space by the crack users could also been seen, as police control increased significantly, forcing the users to move about the streets much more - even though they still maintained certain points of concentration, as observed. We frequently had the impression that when the police ${ }^{29}$ showed up the users would disperse but then return - slowly or quickly - to the same places.

27 A probable reference to a song by Rita Lee.

28 In areas nearer to the pentagon, inside which the demolitions of 2007 took place, there was apparently a reduction in the number of crack users. But this cannot be stated definitely. For example, when we imagined that we had understood this territoriality a little better, we discovered from shopkeepers that at night there was another large gathering of users of crack who came onto the streets at night at the corner of Guaianazes and Gusmões Streets, only after local establishments closed their doors.

29 Constantly identified by users as "loira" (the "blonde"). 
We listened to the comments of a person who attended the reception center of É de Lei, and who lives with his parents in a block of flats on Helvétia, almost on the corner of Ana Cintra Street. Since he lives near a place where many users gather, he always commented on the drug use in the region. Once, one of the agents asked if there were many users on the street that morning. He said there were because the number had been gradually rising since the police operations that had begun there in October, had stopped in November 2008, although there was always a police car parked on Helvétia Street, which he said“is now the cracolândia of four years ago.”

Although most users were on the corners and pavements of Helvétia a few blocks from the "pentagon," we could see that this was not the only area occupied, since we also watched the distribution of materials in the Júlio Prestes and Princesa Isabel squares, as well as on Protestantes and Gusmões Streets. There were also a significant number of users at night, near Guaianazes and Gusmões, but only after the local shops close their doors, very probably due to a different set of agreements.

On the other hand, the increase in the attended area is not only because of the events and interventions in the last decade. The fact that É de Lei has carried out field work in areas near the "pentagon" since at least 2003 suggests the presence of users in these areas even before Operation Clean Up in 2005. Besides, when the itinerary to be followed by the team in the distribution of materials was presented during one of the organization's field routes, one of the members of É de Lei remembered that in previous years, the actions included some slightly more distant areas, including some outside the perimeter of the Luz neighborhood, like the República and Sé Squares, and the neighborhoods Baixada do Glicério and Pari.

Thus, we look at the mapping of a cracolândia principally from the perspective of É de Lei. In this ethnography, it emerges with no actually fixed territory, even though this does not mean that it is dislocated. As Marina observed, "cracolândia" is located in the area where the users are, or at least most of them: “... cracolândia does exist. It's not only a geographical space. It is the world of crack cocaine. There are 20 people around you, fissuradas (strung out on the drug).” 


\section{The impacts of a broadened ethnographic context: new questions for deeper study}

The situation described underwent changes after the inauguration of the "Ação Integrada Centro Legal" ("Integrated Action for a Legal Downtown"), in the middle of the following year (2009) in the Luz district. ${ }^{30}$ In a certain way, the program readopted some general principles of Operation Clean Up (2005), whose ostensive police patrols in the area continued, though to a lesser degree and more variably, in the following years, with a series of repressive interventions undertaken during the Administration of Mayor G. Kassab. ${ }^{31}$ This program established a certain continuity, combining police action with that of other sectors and government agencies. Nevertheless, people related to the use of crack cocaine and to other illegal activities remained in the region (although continually moving around the downtown area) - even after the demolition of many buildings after Operation Clean Up, and especially after the Nova Luz project (2007) was decreed. The permanence of these activities required the application of other forms of intervention in the neighborhood.

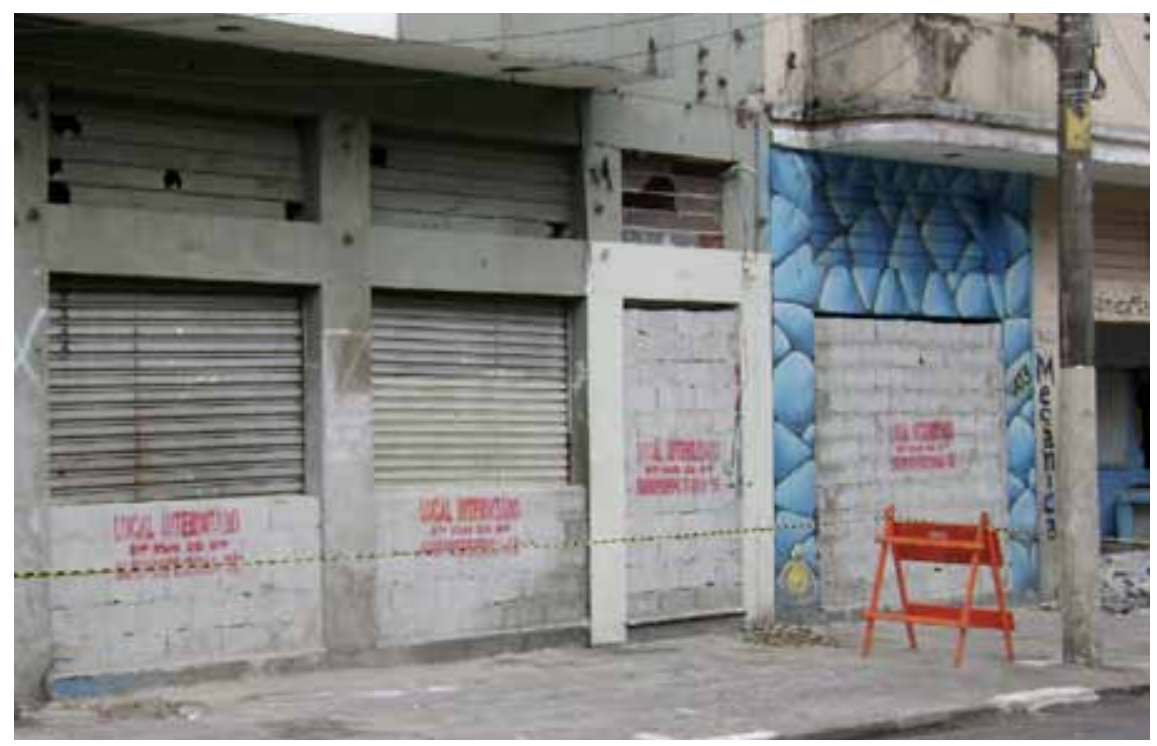

Establishments in Luz closed down after Operation Clean Up (2005) (photo: Heitor Frúgoli Jr.).

30 Authorized by the Public Ministry, and including joint action by the Military and Civil Police, inspection authorities and health inspection (Folha Online, 22/7/2009).

31 G. Kassab was vice mayor in the J. Serra administration (PSDB-PFL, 2005-2006) and took over City Hall in 2006 (he joined the DEM (former PFL) after March 2007); and was elected to a four year term in 2009. 


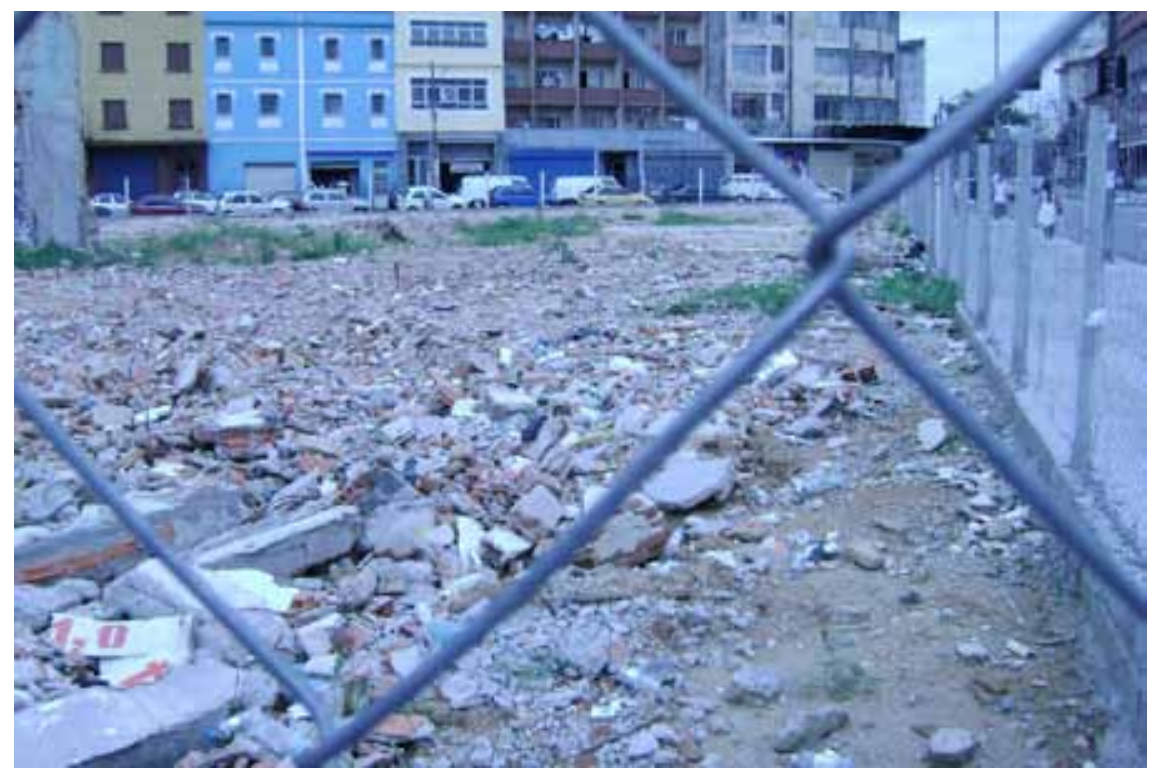

View of the area demolished on the corner of Protestantes and Mauá Streets (photo: Heitor Frúgoli Jr.).

In a conversation in October 2008, agents of É de Lei said that they had noticed a gradual change in the way in which the government was facing the question of cracolândia. What had before been treated as a social problem, began to be recognized as a "health issue," although Marina pointed out that this was still far from ideal, since the policy was restricted to the hospitalization of users and police action continued to be repressive.

This new way of tackling the cracolândia "problem" would appear more strongly in 2009, when local government began a new intervention in the Luz neighborhood and surroundings by means of the so-called "Integrated Action for a Legal Downtown" (Corsalete, 23/7/2009). But this was connected as before to considerable interests in the urban sphere. In the middle of the first semester of 2009, a controversial plan of "urban concession" was passed by the São Paulo city council and sanctioned by the mayor on May 7,2009. It includes the expropriation of 18 blocks in the central region (about 6oo properties) with participation of the private sector. At the same time, cracolândia began to be regarded, in the words of the mayor, as a "health problem." "This entire revitalization will only be possible when we succeed in minimizing this problem," said Mayor Kassab. (Portal Terra, April 23, 2009, our translation). Within this framework of various interests, the mayor formed teams of health workers to "help the chemical addicts of Nova Luz" through projects 
in other spheres (Globo.com, April 24, 2009, our translation).

These developments raised new questions about what we had been attempting to analyze about cracolândia as an itinerant territoriality, characterized by a certain mobility, and which was related to social actors within the dynamics of work, trade, housing and leisure in "degraded" areas. Previous observations had allowed us to relativize certain territorial determinations about a perimeter that defined the main target of repression and investment by the authorities during the last decade and where some demolitions began in 2007. However, the challenge remained to understand the impact of new political and social dynamics on the context after 2009.

Although it was not possible to conduct an ethnographic study of the region in question at the time of Operation Clean Up (May 2005), it seems to us that aspects of that situation, especially the dispersion of users of crack to other downtown areas reappeared (in new arrangements) after the Integrated Action for a Legal Downtown (from July 2009 onwards). ${ }^{32}$ This especially became clear when the national media began to criticize the efficiency of the eradication of the use of crack in the Luz neighborhood. It also showed the presence of user groups in other downtown areas, such as the neighborhoods of Barra Funda the Anhangabaú Valley and the República Square. According to one article, the region of cracolândia spanned the neighborhoods of Bom Retiro, Luz, Santa Cecilia, República and Arouche (O Globo, July 23, 2009), and the users had become the "exiles from cracolândia" (Sampaio, Aug. 9, 2009, our translation). ${ }^{33}$

Some aspects observed in our contacts in the Projeto Quixote (the Quixote Project), ${ }^{34}$ which works with children and young people in situations of risk in various areas of downtown São Paulo, including the so-called cracolândia are worth mentioning to make the themes dealt with here easier to understand.

32 Our investigations show scores of articles about this during July 2009.

33 See the publications: Capriglione, 26/06/2009; Spinelli; Credendio, 02/07/2009; Estadão, 22/07/2009; Magalhães, 22/07/2009; O Globo, 23/07/2009; Manso; Zanchetta, 12/07/2009b. For more details, see the excellent study of publications in the national media produced by Karina Fasson and Bruno Puccinelli, members of GEAC (Fasson; Puccinelli, 2010).

34 The Quixote Project, created in 1996, is registered as a not for profit Organization of Civil Society in the Public Interest (OSCIP), and is connected to the Federal University of São Paulo - UNIFESP. We stayed in contact with one of the coordinators but unfortunately it has not been possible to accompany the relations of the educators with their target public ethnographically. 
In 2008,35 Fernanda Quirino Ramos, an assistant therapist and one of the coordinators of the organization, told us that in various places downtown there was a certain contrast between the dynamics observed in the Anhangabaú Valley - a more open public area, where it is easier to interact with children and young people, where educational activities are more viable and where the use of drugs is rarer - and the Luz neighborhood. In Luz, there is not much room for interaction, fewer resources for making contacts, and the use of crack is much more intense. Various children and young people move around both territories. In the Anhangabaú Valley (or other downtown areas, like República) they may open up to interaction with educators, but in cracolândia they frequently say: "here, no!" or "mister, pretend you don't see me!"

The next year, weeks after the beginning of "Operation Legal Downtown," the same coordinator pointed out ${ }^{36}$ the consequences of the significant increase in police repression (which had already begun ): children and young people were forced to walk around a great deal, it was more difficult to interact with them, and access to crack was apparently easier than before in various places. ${ }^{37}$

According to Fernanda, it is also common for these children and young people to tell the educators that they use crack but that they are not noias (as we saw in some ethnographic situations with É de Lei). Sometimes, one user may call another a noia as a kind of moral insult, since the person accused is losing a certain "discernment" according to the coordinator. If someone states that "at one time I was a noia," he may be speaking not only of a period in which he used crack, but in which, in Fernanda's words, he lacked "dignity." Use of the term noia can be considered inherent to the relations among these crack users or "craqueiros" ["crackheads"].

On the day of our visit to one of the branches of the Quixote Project (located in Republic Square) in July 2009, we witnessed a scene similar to those we had seen before. A group of approximately 20 users (adults) were gathered on Joaquim Gustavo Street (most of them sitting on the ground and some with pipes in their hands).When the police came slowly in their direction, they all immediately dispersed and most went towards São João Avenue.

35 The interview was conducted on Oct. 20, 2008.

36 In an interview on July 23, 2009.

37 Within the principle that, with the repression, the dynamic of cracolândia would begin to spread to other downtown areas. 
About 15 minutes later, however, a number had already returned.

Another very important contact was established with Osvaldo Ataíde Norberto - although only once. He is an educator who works in the streets and a member of the Fundação Projeto Travessia ${ }^{38}$ whose target public is also children and adolescents living in the streets. The first aspect that attracted our attention was his use of a series of anthropological concepts that has guided his work since 2004 in the region of cracolândia: thinking of the children and adolescents of that context as "natives" (seeking to avoid pre-conceived ideas about them); becoming close to them and interacting, based on the idea of "participative observation"; understanding certain kinds of discourses ("made for the colonizer"); paying attention to their "ritual practices" and seeking to recognize the "reading they have of us" (as opposed to what we have of them) etc.

Norberto found that the children and adolescents did not talk about the Luz region (some asked "what's that?," when asked by him), but of cracolândia, and although they use crack, many do not see themselves as noias (this would be a category used more by those "from outside"). ${ }^{39}$ So-called cracolândia is not limited to a single physical place - since they "take it wherever they go," nor is it limited by the use of crack ("just one element in the situation"). He also found that these children and adolescents often establish close relationships with homeless people, shopkeepers, prostitutes, those collecting trash for recycling, street vendors etc. ${ }^{40}$

Other investigations have allowed us to broaden our observations (as well as the understanding of the challenges) about topics regarding concrete points about territoriality, fields of relationships and identity constructions in this context. An ethnographic study by Selma L. da Silva (2000) about women and the use of crack in the Luz neighborhood ${ }^{41}$ for instance, syntheti-

38 Travessia Project Foundation. Interview held on 15/10/2008 and unfortunately not followed up, despite countless attempts to meet Osvaldo again. After, he left the institution.

39 According to Osvaldo, they think; "I'm not a noia, I just can't manage to stay in my house" (Coletivo Política do Impossível, 2008, 9o, our translation).

40 Not to mention those that are implicit when they speak, such as NGOs, the police, employees of the local authorities or evangelicals, although all of them may be thought of more, in this case, as agents who have access to cracolândia.

41 The researcher provided details of this study at a seminar held by GEAC on March 6, 2009. Her investigation was developed with the practices of the facilitating agents connected to the Casa de Convivência da Pastoral da Mulher Marginalizada (a religious organization to help vulnerable women), connected to the Diocese of São Paulo. 
cally calls attention to the multifaceted context found in the district and in the region. She interacted with women who practiced prostitution and with others who were in the street, involved in other activities (sometimes theft or drug dealing) which in itself defined certain distinctions among them. She perceived that there were prostitutes that smoked crack and others who did not, and between them there was conflict resulting from the fact that the crack users tended to charge less for a program or would agree not to use condoms, causing problems for the others who then called them "noias" or "noinhas" ("little noias") as well as "crackeiras" ("crackheads") or "fedidas" ("smelly girls") (Silva, 2000, 54-63).

Besides this, those who smoked crack also believed that they could take some precautions (such as alternating consumption with water, milk, soft drinks, or food, taking a bath or resting, leaving a longer time between the days when it was used, or not staying in the streets with the others). This for example is expressed in the following words: "the rock doesn't control me, I control the rock" (Silva, 2000, 75, our translation). In this context, the term noia may also be used by women who use crack for those who cannot deal with the more harmful effects of the drug and who practice high-risk behavior. ${ }^{42}$

However, considering the uses of the concepts of cracolândia, and noias (as well as crack users), the question remains of how to describe this itinerant territoriality. An ethnographic observation of the uses and disputes that permeate the Luz neighborhood demands an analysis of the plurality of actors involved with cracolândia as well as of the connections among them, whether conflicting or not, which paint a complex and heterogeneous picture of relations. These factors and relations are barely touched upon in journalistic approaches and media reports on the theme.

Based above all on the ethnographic analysis of the work of one of the various organizations that attends crack users in the Luz neighborhood, this paper presents some of the relations established by authorities with these agents. The work of É de Lei is an example of a possible mediation between users and the authorities or "society," in general, the aim of which is to create a non-conflicting relation, characterized by discourse on harm reduction in the use of drugs. This is one way to mediate, among many others that we

42 See more details in Silva (2000, 72-82). In the space of this article it will unfortunately not be possible to show the results of another investigation underway in Luz, related to the field of prostitution. 
observed from the beginning of the study including: police action; the participation of shopkeepers in the Luz neighborhood and nearby in the daily life of the district; the work of private guards and security officers ${ }^{43}$ hired by shop and parking lot owners to keep users away, who also force users to move continuously around various streets in the region; as well as the involvement of people who live in residential buildings in the region.

The conclusion of this paper actually points to the beginning of a series of challenges that arose from those first ethnographic moves to come closer to the subject, to be able to understand so-called cracolândia as a modality of itinerant territoriality and a field of relationships in a multifaceted context marked by diverse situational variations. Throughout this text, we have observed various connections between the terms cracolândia, crack users and noia. The terms must be separated for analytical purposes.

The term cracolândia emphasizes a certain territorial dimension, with a tendency to be fixed spatially from the point of view of how it is represented, as in fact occurred in the Luz neighborhood, which practically became a synonym for cracolândia in various newspapers (although these also recognize that after large-scale repressive operations by the police and other agencies, this context "migrates" or "reappears" elsewhere). It is clear that the authorities have used the term to describe an urban region within a specific perimeter that is to be "remodeled." In any case, it cannot be said that the term is only used by the authorities or by the media since it is also used by users of crack themselves.

One type of ethnographic approach is faced by the problem of the supposedly fixed nature of this territoriality, when users of crack deal with police actions in their daily lives, or when they gradually create (as well as dissolve) new concentrations in other places in the city. It is important to note that this observation was only possible when we observed how the so-called cracolândia is embodied in the users or consumers of crack. Although they are not the only actors in this space, they undoubtedly constitute the main targets of a series of interventions, mediation or control. Nevertheless, we know that this category, although it is decisive, may often be relative, provisional or insufficient (as is all identity construction). We frequently came into contact with people who are part of this area of relationships but who do not use crack or other drugs.

43 There are also reports of the presence of people linked to the criminal organization PCC (Primeiro Comando da Capital (First Capital Command), which acts in the region, organizing where the noias can stay so as not to upset the local establishments. 
Finally, special attention must be paid to the way in which various (and fractal) meanings are attached to the emic term noia, which is perhaps revealed in this context to be the main relational category. It dialogs with, but is not identical to, "crack user" as we have seen - and is used in a significant series of situations to identify those who use crack, whether by residents, shopkeepers, and others who frequent the Luz neighborhood, or by those who actually use crack, which reveals stigmatizations among users - with moral dimensions related to an ability to in some way control the effects of the drug.

This is not to mention references which may occur, as we have seen in other ongoing ethnographic situations in the Luz neighborhood, which are made jokingly by non-users. ${ }^{44}$

These observations that are derived from our observations in the field pose a series of new challenges for our current and ongoing research at a time when the use of crack is becoming an increasing concern in Brazil. Serious attention must be paid to news that refers to the "spread of cracolândias" throughout Brazilian cities. What is at stake in each of these arrangements must be understood at multiple levels and with emphasis on an ethnographic perspective as we have sought to contribute to here.

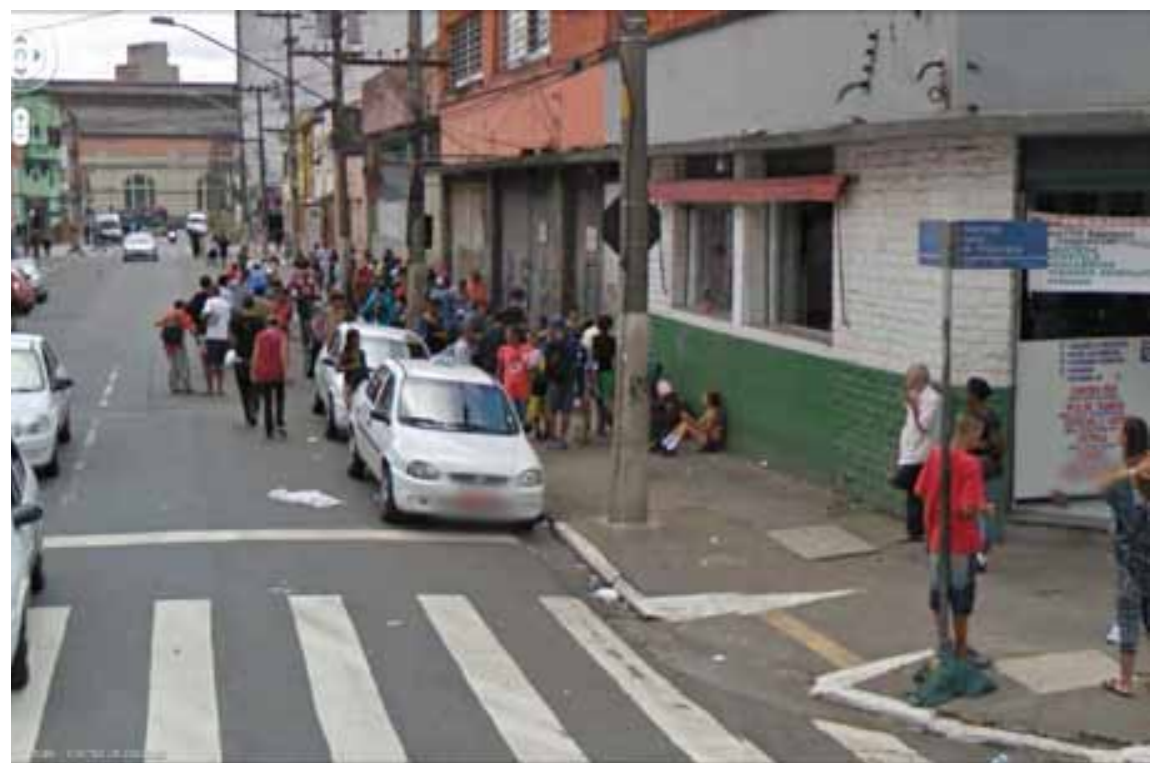

View of Helvétia Street: many of these people are crack users (photo: Google Maps).

44 When we accompanied the relations between members of a local amateur team (Nova Portuguesinha da Luz) at a snack bar in the neighbourhood, a boy asked why he had not been chosen to play that day, and the person in charge answered, "because you are a noia!", which was followed by a great deal of laughter. 


\section{Bibliography}

\section{Books, academic journal articles, dissertations and research reports}

AGIER, Michel. 1999. L'invention de la ville. Banlieues, townships, invasions et favelas.Paris: Archives Contemporaines.

AGIER, Michel. 2009. Esquisses d'une anthropologie de la ville: lieux, situations, mouvements. Louvain-la-Neuve : Bruylant-Academia.

AUTHIER, Jean-Yves; BACQUE, Marie Hélène.; GUERIN-PACE, France (ed.). 2006. Le quartier: enjeux scientifiques, action politiques et pratiques sociales. Paris: La Découverte.

ARANTES, Antônio A. 1996. "The war of places: symbolic boundaries and liminalities in urban space". Theory, Culture \& Society, 13: 81-92.

BOURDIEU, Pierre. 2007 [1979]. A distinção: crítica social do julgamento. Porto Alegre: Zouk.

BOURGOIS, Philippe. 1989. “Homeless in El Barrio”. In: P. Bourdieu(org.), A miséria do mundo. Petrópolis: Vozes. pp. 203-214.

BOURGOIS, Philippe. 2003. In search for respect: selling crack in El Barrio. Cambridge: Cambridge University Press.

CERTEAU, Michel de. 1994 [1980]. A invenção do cotidiano: 1. Artes de fazer. Petrópolis: Vozes.

CORDEIRO, Graça Índias. 2003. "A antropologia urbana entre a tradição e a prática”. In: G. I. Cordeiro; L. V. Baptista e A. F. Costa (orgs.), Etnografias urbanas. Oieiras: Celta Ed. pp. 3-32.

DURHAM, Eunice R. 2004 [1986]. "A pesquisa antropológica com populações urbanas”. In: A dinâmica da cultura. São Paulo: Cosac \& Naify. pp. 357-376.

ECKERT, Cornelia. 2010. "Cidade e política: nas trilhas de uma antropologia da e na cidade no Brasil”. In: L. F. D., Duarte (org.), Horizontes das ciências sociais no Brasil: antropologia. São Paulo: ANPOCS. pp. 155-196.

FASSON, Karina; PUCCINELLI, Bruno. 2010. "Pensando o crack na cidade de São Paulo: cracolândia, intervenções públicas, saúde e marginalização”. In: IX Concurso Nacional de Monografia sobre Drogas, Secretaria Nacional de Políticas sobre Drogas, Brasília. (no prelo).

FERNANDES, Luís. 1995. “O sítio das drogas: etnografia urbana dos territórios psicotrópicos”. Toxicodependências, 1(2): 22-31, Ed. IDT. http:/| repositorio-aberto.up.pt/bitstream/10216/56439/2/39361.pdf

FERNANDES, Luís. 2000. “Social peripheries and drugs: an ethnographic 
study in psychotropic territories”. In: G. Greenwood and K. Robertson (ed.), Understanding and responding to drug use: the role of qualitative research. Lisbon: European Monitoring Centre for Drugs and Drug Addiction. pp. 143-148. http://repositorio-aberto.up.pt/bitstream/10216/22929/2/66oo8.pdf FERNANDES, Luís; RAMOS, Alexandra. 2010. “Exclusão social e violências quotidianas em 'bairros degradados': etnografia das drogas numa periferia urbana". Toxicodependências, 16(2): 15-27. Ed. IDT http://www. scielo.oces.mctes.pt/pdf/tox/v16n2/v16n2ao2.pdf

FRÚGOLI JR., Heitor. 2000. Centralidade em São Paulo: trajetórias, conflitos e negociações na metrópole. São Paulo: Cortez/Edusp/Fapesp.

FRÚGOLI JR., Heitor. 2006. “Intervention dans les espaces centraux des villes brésiliennes, le cas de São Paulo”. In: H. Rivière D’Arc \& M. Memoli (eds.), Le pari urbain en Amérique Latine. Paris: Armand Colin. pp. 133-147.

FRÚGOLI JR., Heitor. 2007. Sociabilidade urbana. Rio de Janeiro: Jorge Zahar. FRÚGOLI JR., Heitor. 2008. “Abordagens etnográficas sobre o bairro da Luz (São Paulo): gentrification em questão na antropologia”. Projeto de pesquisa para o Edital MCT/CNPq 14/2008 - Universal.

FRÚGOLI JR., Heitor; ADERALDO, Guilhermo A. 2010. “Abordagens etnográficas no bairro da Luz, São Paulo: frentes articuladas de investigação". Paper para a $27^{\underline{a}}$ Reunião Brasileira de Antropologia, Belém, ago. 2010.

FRÚGOLI JR., Heitor; sklair, Jessica. 2008. “The Luz district in São Paulo: anthropological questions on the phenomenon of gentrification". Paper para o IX Congresso Internacional da BRASA (Brazilian Studies Association), New Orleans, Tulane University, Mar. 2008. http://sitemason.vanderbilt. edu/files/gO5Hfq/Frugolisklair.doc

FRÚGOLI JR., Heitor; sklair, Jessica. 2009. “O bairro da Luz em São Paulo: questões antropológicas sobre o fenômeno da gentrification”. Cuadernos de Antropología Social, 30: 119-136.

GEERTZ, Clifford. 1997 [1983]. O saber local: novos ensaios em antropologia interpretativa. Petrópolis: Vozes.

JOSEPH, Isaac. 2005 [1998]. “A respeito do bom uso da Escola de Chicago”. In: L. P. Valladares (org.), A Escola de Chicago: impactos de uma tradição no Brasil e na França. Belo Horizonte \& Rio de Janeiro: Ed. UFMG/ IUPERJ. pp. 91-128. KARA-JOSÉ, Beatriz. 2007. Políticas culturais e negócios urbanos. São Paulo: Annablume/Fapesp. 
LABATE, Beatriz C. et al. (org.). 2008. Drogas e cultura: novas perspectivas. Salvador: EDUFBA.

MAGNANI, José Guilherme C. 2005. "From close up and within: notes for an urban ethnography”. Revista Brasileira de Ciências Sociais, 1, São Paulo (translation to English of "De perto e de dentro: notas para uma etnografia urbana" [2002]): http://socialsciences.scielo.org/scielo. php?pid=S0102-69092005000100002\&script=sci_arttext

MINGARDI, Guaracy; GOULART, Sandra L. 2001. "As drogas ilícitas em São Paulo: o caso da cracolândia”. Coleção Revista ILANUD, 15, São Paulo. PAQUOT, Thierry. 2009. “Qu'appelle-t-on un territoire?”. In : ; C.

Younès (eds.), Le territoire des philosophes. Paris : La Découverte. pp. 9-27.

PEIRANO, Mariza. 2005. "A guide to anthropology in Brazil”. Vibrant - Virtual Brazilian Anthropology, 2(1/2) : 54-87. jan./ dez. Brasília. http://www.vibrant. org.br/downloads/v2n1_agab.pdf

PEIXOTO, Paulo. 2009. “Requalificação urbana”. In: C. Fortuna; R. P. Leite (orgs.), Plural de cidade: novos léxicos urbanos. Coimbra: Almedina. pp. 41-52. PERLONGHER, Néstor. 1987. O negócio do michê. São Paulo: Brasiliense. 2ª ed.. PERLONGHER, Néstor. 1991. "Droga e êxtase” (primeira versão). Cadernos IFCH, 34:1-18, Unicamp, Campinas.

PERLONGHER, Néstor. 2005 [1988]. “Territórios marginais”. In: J. N. Green;

R. Trindade (orgs.), Homossexualismo em São Paulo e outros escritos. São Paulo: Ed. Unesp. pp. 263-29o.

PFAUS, Guillaume. 2004. “Espoir Goutte d'Or. Intervention communautaire et réduction des risques", Projet 5/2004, 282 : pp. 73-75. www.cairn.info/ revue-projet-2004-5-page-73.htm

RUI, Taniele C. 2011. “Fronteiras, espaços e usos”. Paper para 0 35 Encontro Anual da ANPOCS, Caxambu, out./2011.

SILVA, Selma L. da. 2000. Mulheres na Luz: uma etnografia dos usos e preservação no uso do crack. Dissertação de mestrado, Departamento de Práticas de Saúde Pública da USP, São Paulo.

Press materials, documents and others

"A encrenca do crack: 'Raspa da canela do diabo', droga se espalha pelo país”. Folha de S. Paulo, 23/5/2010, São Paulo. http:/|www 1.folha.uol.com.br/fsp/ ilustrissima/il2305201004. Acesso em: 23/5/2010.

"Ação contra crime na cracolândia em São Paulo prende nove". Folha Online, 
22/7/2009, http: |/www1.folha.uol.com.br/folha/cotidiano/ult95u598685. shtml. Acesso em: 22/7/2009.

BRANDALISE, Vitor H. "Nunca vi cracolândia tão sociável (Philippe Bourgois, antropólogo americano)". O Estado de São Paulo, São Paulo, 10/12/2010, http://www.estadao.com.br/noticias/impresso,nunca-vicracolandia-tao-sociavel-diz-expert,65209o,o.htm. Acesso em: 27/8/2011. COLETIVO POLÍTICA DO IMPOSSÍvel. 2008. "Cidade de quem? - Conversa com Osvaldo". In: Cidade Luz: uma investigação-ação no centro de São Paulo. São Paulo: Ed. PI. pp. 88-97.

CORSALETE, Conrado. "Ação na cracolândia prende 5 a atende 41". Folha de São Paulo, São Paulo, 23/7/2009, C8.

"Kassab diz que terá gabinete na Cracolândia". Portal Terra, 23/4/2009. http:// noticias.terra.com.br/brasil/interna/o,,OI3720836EI78 96,ooKassab+diz+qu e+tera+gabinete+na+Cracolândia.html. Acesso em: 23/4/2009.

MAGALHÃES, Vagner. 2009. "SP inicia megaoperação contra drogas no Centro”. Redação Terra, São Paulo, 22/7/2009. Disponível em: http:// noticias.terra.com.br/brasil/interna/o,,OI3887155- EI5030,ooSP inicia megaoperacao contra drogas no Centro.html. Acesso em: 22/7/2009. MANSO, Bruno P.; zanchetta, Diego. 2009. "Circuitos da pedra extrapolam Nova Luz”. Estadão, São Paulo, 12/7/2009. Disponível em: http://www. estadao.com.br/estadaodehoje/20090712/not_imp4013 78,o.php. Acesso em: 12/7/2009.

MONTEIRO, Karla. 200o. "O vocabulário do usuário de crack". Folha de São Paulo, São Paulo, 3/9/2000, $C_{3}$.

NOVA LUZ (Lei 14.096 de 12/8/2005). Prefeitura do Município de São Paulo, São Paulo, dez./2005.

"Operação destrói mais 13 imóveis na cracolândia no Rio". Folha Online, 21/5/2010. http: //www1.folha.uol.com.br/folha/cotidiano/ult95u738806. shtml. Acesso em: 21/5/2010.

"PM faz na zona norte do Rio a maior apreensão de crack deste ano". Folha Online, 19/5/2010. http: /|www1.folha.uol.com.br/folha/cotidiano/ ult95u737497.shtml. Acesso em: 19/5/2010.

"PM prende 58 em cracolândia na zona norte do Rio". Folha Online, 17/5/2010. http: //www1.folha.uol.com.br/folha/cotidiano/ult95u73640o.shtml. Acesso em: 17/5/2010.

"Polícia promete ampliar cerco ao tráfico de drogas na Cracolândia, em SP". O 
Globo, Rio de Janeiro, 23/7/2009. Disponível em: http://oglobo.globo.com/ cidades/sp/mat/2009/07/23/policia- promete-ampliar-cerco-ao-trafico-dedrogas-na-cracolândia-em-sp- 756937684.asp. Acesso em: 23/7/2009.

"Prédios abandonados viram cracolândia e são ameaça". Diário do Nordeste, Fortaleza, 31/5/2010,. http://diariodonordeste.globo.com/materia. asp? codigo=793633. Acesso em: 31/5/2010.

"Prefeitura de SP quer formar agentes de saúde para atuar na cracolândia". Globo.com, 24/4/2009, http:/|g1.globo.com/Noticias/ SaoPaulo/o,,MUL1097760-5605,00-PREFEITURA DE SP QUER FORMAR AGENTES DE SAUDE PARA ATUAR NA CRACOLÂNDIA.html . Acesso em: 24/4/2009.

"Raio X da 'cracolândia". Folha de São Paulo, São Paulo, 10/3/2005, p. C-8.

"Rio destrói 80 imóveis e recolhe 23 pessoas em operação contra cracolândia". Folha Online, 20/5/2010. http: /|www1.folha.uol.com.br/folha/cotidiano/ ult95u73840o.shtml. Acesso em: 20/5/2010.

SAMPAIO, Paulo. 2009. "Exilados da cracolândia vagam pelo centro de São

Paulo". Folha de S. Paulo, São Paulo, 9/8/2009. http://www1.folha.uol.com. br/folha/cotidiano/ult95u607155.sh tml. Acesso em: 9/8/2009 UCHÔA, Marco A. 1996. Crack: o caminho das pedras. São Paulo: Ática.

\section{About the authors}

Heitor Frúgoli Jr. is Professor in the Department of Anthropology of the Faculty of Philosophy, Literature and Languages, and Human Sciences at the University of São Paulo (FFLCH-USP), coordinator of the Anthropology of the City Study Group (GEAC-USP) and researcher of the National Council for Scientific and Technological Development (CNPq); his last book was Sociabilidade Urbana (Rio de Janeiro, Jorge Zahar, 2007).

E-mail: hfrugoli@uol.com.br

Enrico Spaggiari is $\mathrm{PhD}$ degree student in Social Anthropology at the University of São Paulo (USP) and São Paulo Research Foundation (FAPESP) scholar. The author is participant of the Anthropology of the City Study Group (GEAC-USP) and LUDENS - Interdisciplinary Center for the Study of Football and Ludic Modalities.

E-mail: enricospaggiari@yahoo.com.br 
Received September 13, 2011, approved November 11, 2011 